\title{
ODRZUCENIE CZY AKCEPTACJA? HOLLYWOOD W HOLANDII ${ }^{1}$
}

Podobnie jak fotografia, film jest mechaniczną formą sztuki. Debata o statusie filmu jako sztuki jest nierozerwalnie połączona $\mathrm{z}$ debatą o mechanizacji i standaryzacji kultury, która rozgorzała w Europie i Ameryce na początku XX wieku. Głównie ze względu na fakt, iż Ameryka wyprzedzała Europę w tym, co holenderski historyk Johan Huizinga nazywa „instrumentalizacją życia”, wielu miało zwyczaj przypisywania tych apokaliptyczny trendów właśnie Ameryce. Rzadko kiedy decydowano się w spokoju rozważyć, czy procesy mechanizacji i standaryzacji - niezależnie od źródła ich pochodzenia - mogły mieć odmienne efekty w Europie i Ameryce oraz czy mogły one przynieść różne skutki w zależności od kontekstu historycznego i różnych sposobów myślenia dominujących w danych kulturach. Tymczasem przeważały tendencje do zajmowania pozycji, wedle której proces mechanizacji przyjął postać amerykańską, a Europa może się z nim zetknąć tylko w takiej postaci.

Warto też dostrzec, że również wielu obrońców kultury w samej Ameryce martwiło się komercjalizacją, mechanizacją i standaryzacją. Wystarczy wspomnieć Henry'ego Adamsa, potomka jednej z najważniejszych amerykańskich rodzin, i jego obawę o utratę duchowości przez kulturę jego ojczyzny. Adams miał głębokie poczucie otaczającego go rozkładu i degeneracji, które dzielił z innymi Amerykanami o podobnym statusie społecznym. Kolejny „ekscentryk z Nowej Anglii”, Charles Ives, tak wyrażał się w swoich dziennikach:

Ale zamierają nie tylko wiece religijne (camp meetings). Co z korzeniami 1776 roku? Istnieje prawdopodobnie kilka powodów tego stanu rzeczy. Być może najbardziej oczywistym, jeśli nie najbardziej szkodliwym, jest komercjalizacja pchająca w kierunku mechanizacji i standaryzacji procesów umysłowych i życiowych (czyniąca zarówno śniadanie, jak i śmierć nieznośnie lekkimi). Kastrowanie Ameryki dla pieniędzy! Czy Anglosasi stają się pantoflarzami?²

W wypowiedzi tej można wyczuć obawę, iż dumna anglosaska część narodu staje się jałowa w obliczu nowo powstającej kultury konsumpcji ijej płytkich przyjemności.

1 Niniejszy tekst jest znacznie rozbudowaną wersją artykułu opublikowanego w „American Studies International” 1990, Vol. XXXVIII, s. 37-52.

2 Memos, eds. J. Kirkpatrick, Ch. E. Ives, New York 1972, s. 120. 
W Europie narzekał podobny chór zgodnych głosów. W 1927 roku Francuz André Siegfried stwierdził:

za taki luksus w zasięgu każdego robotnika trzeba zapłacić wysoką cenę. Jest ona niczym innym, jak transformacją milionów pracowników w automaty. Fordyzm, czyli esencja amerykańskiego przemysłu, skutkuje standaryzacją robotnika jako takiego. W Nowym Świecie nie ma już miejsca dla kunsztu. Razem z nim zniknęly te koncepcje człowieka, które w Europie uważamy za podstawę cywilizacji ${ }^{3}$.

To co w przypadku Ivesa nadal było postrzegane jedynie jako rezultat procesu mechanizacji, z punktu widzenia Siegfrieda przyjmuje postać amerykańsko-europejskiego starcia. $Z$ tego względu Johan Huizinga, patrzący z szerszej perspektywy, dostrzega w Ameryce pierwsze oznaki znacznie bardziej ogólnych zmian cywilizacyjnych: „Organizacja staje się mechanizacją; to jest ten fatalny moment we współczesnej historii cywilizacji”" Jednakże szerokość jego spojrzenia nie łagodzi poczucia upadku kultury. Co więcej, Huizinga jest świadom, że bez mechanizacji nie będzie cywilizacji w ogóle: „Proces udoskonalania kultury jest nierozerwalnie połączony z instrumentalizacją”. Niemniej wywołuje on dwa odmienne skutki: ma siłę wiązania i siłę uwalniania. Teraz pojawia się („Ameryka jest tego perfekcyjnym przykładem”), jak gdyby równowaga skierowała się bardziej w stronę tego pierwszego, ku uległości i uwiązaniu jednostki, zamiast w kierunku jej wyzwolenia. Huizinga przechodzi następnie do rozważań, czy instrumentalizacja amerykańskiego życia mogłaby działać tam inaczej niż w Europie.

Organizacja w duchu standaryzacji oznacza ustanowienie jednolitej, dobrze określonej nomenklatury technicznej [...] dla Amerykanów nie jest to zło konieczne, ale indywidualna potrzeba, a nawet ideał kulturowy [...]. Zrozumie to każdy, kto zna zna ich poczucie konformizmu i zbiorowej tożsamości. Amerykanin chce być taki sam jak jego sąsiedzi. Czuje się duchowo bezpieczny tylko $\mathrm{w}$ normatywnie urządzonym środowisku, przy czym z tego drugiego wynika także „efektywność”.

${ }^{3}$ A. Siegfried, Préface, [w:] A. Phillip, Le problème ouvrier aux Etats-Unis, Librairie Félix Alcan: Paris 1927, s. XIII.

${ }^{4} \mathrm{Na}$ temat poglądów Huizingi w sprawie mechanizacji współczesnego życia warto zajrzeć do jego Mensch en menigte in Amerika (Tjeenk Willink: Haarlem 1918, rozdz. II) oraz Denkend Mensch en Menigte (Tjeenk Willink: Haarlem 1927, s. 14). Obie książki zostały przetłumaczone na język angielski przez Herberta H. Rowena i wydane w jednym tomie zatytułowanym America: A Dutch Historian's Vision - From Afar and Near, Harper and Row: New York 1972. 
Siegfried rozwija ten kontrast:

Zaś co do przedstawicieli ras, które są indywidualistami w pracy - Francuza, który kładzie nacisk na myślenie o sobie i przez siebie; przedstawiciela kultury śródziemnomorskiej z jego talentem do ogrodnictwa i uwielbieniem ziemi - oni wszyscy agresywnie podkreślają swoją indywidualność, tak jakby nie mogli wpasować się w amerykańską MASZYNERIĘs.

Prowadzi nas to z powrotem do jednej z klasycznych opozycji, które Europejczycy mają skłonność dostrzegać między nimi samymi a „Ameryką”: indywidualna heterogenia przeciwko jednolitości mas. Opozycja ta, podobnie jak $\mathrm{w}$ wielu innych przypadkach, jest taktycznym kuglarstwem przeznaczonym do utrzymywania amerykańskiego zagrożenia na bezpieczny dystans. Według tego poglądu Europa jest po prostu odporna na wplyw amerykańskiego stylu.

Jedynie Georges Duhamel dawno zrezygnował z tej nadziei. Według niego Ameryka była przyszłością Europy. Społeczeństwo masowe pojawiłoby się w Europie $\mathrm{w}$ formach, które już przyjęły się w Ameryce. To stamtąd miały one przejść niczym niszcząca fala przez Stary Świat. W jego apokaliptycznej wizji „maszynizm” (le machinisme) i „czlowiek instrument” (l'homme outil) zajmują centralne miejsce. Również i on był skłonny ujmować mechanizację jako utratę ludzkiej indywidualności i kreatywności ${ }^{6}$.

$\mathrm{W}$ niemieckim spojrzeniu na zagrożenia płynące $\mathrm{z}$ mechanizacji można znaleźć ten sam motyw człowieka maszyny, sporadycznie nazywanego Chauffeurmenschen. A jednak nacisk zdaje się tu położony na coś odrobinę innego, na ochronę „ducha narodu” (Volksgeist) i kultury (Kultur), przede wszystkim z ich kolektywnym, nie zaś indywidualistycznym aspektem. Dobrze znanym przykładem z 1920 roku jest książka autorstwa Adolfa Halfelda Amerika und der Amerikanismus $^{7}$ o wybitnie oskarżającym podtytue Kritische Betrachtungen eines Deutschen und Europäers. Na obwolucie wydawca wyłożył sprawę jasno: „Antidotum na Henry'ego Forda. Ktokolwiek przeczyta tę książkę, będzie chroniony przed propagandą amerykanizmu” („Das Gegenstück zu Henry Ford. Wer dieses Buch gelesen hat, ist dagegen gefeit, den Amerikanismus zu predigen!"). Kultura europejska, niemiecka zaś w szczególności („insbesondere der deutschen Kultur”), była skazana na zagładę $\mathrm{z}$ rąk Ameryki nastawionej na materializm i mechanizację życia („,durch das auf Materialismus und Lebensmechanisierung eingestellte Amerika"). Racjonalizacja w żyłach Amerykanów była na porządku dziennym, choćby zabijała to, co ludzkie, w Człowieku („einerlei ob sie den Menschen im

${ }^{5}$ A. Siegfried, Préface, s. XI.

${ }^{6}$ G. Duhamel, Scènes de la vie future, Mercure de France: Paris 1931.

7 A. Halfeld, Amerika und der Amerikanismus: Kritische Betrachtungen eines Deutschen und Europäers, Eugen Diederichs: Jena 1927. 
Menschen tötet"). Wydawca przedstawił książkę jako kontrę w stosunku do znacznie bardziej pozytywnej opinii o Ameryce, która przeważała w niemieckich kręgach przemysłowych (zarówno wśród przedsiębiorców, jak i wśród organizacji robotniczych) - opinii, która postrzegała Amerykę jako urzeczywistnienie racjonalnej organizacji ekonomicznej. Halfeldt i inni konserwatywni krytycy kultury przeciwstawiali się temu poglądowi, podając za przykład wiele negatywnych skutków mechanizacji i racjonalnej organizacji. Halfeld, Niemiec i Europejczyk („Deutscher und Europäer”), w następujący sposób ujął kontrast pomiędzy Europą a Ameryką:

europejski świat charakterów i wspólnoty duchowej wrośnięty w narodową tożsamość [„Europäische Welt der Charaktere, der plastischen Symbole und des im Volkstrum wurzlenden Gemeinschaftsgeistes"] stoi naprzeciw Ameryki ludzi maszyn, którzy z jednej podstawowej zasady sukcesu czerpią porządek wartości - napastliwy w swym ubóstwie i okradający życie z jego odwiecznych sekretów [,ein Amerika der Maschinenmenschen, das aus dem einen Grundprinzip des Erfolges eine Wertordnung von beleidigendster Dürftigkeit ableitet und das Leben seinen ewigen Geheimnisse beraubt"].

Najwyraźniej niewielkie znaczenie ma to, że europejscy komentatorzy, od Karola Marksa do Maksa Webera, swoje wielkie teorie o racjonalizacji i demistyfikacji (Entzauberung) świata tworzyli opierając się wyłącznie na osiągnięciach europejskich. Halfeld czul, że może opisywać Europę jako kontynent, na którym blask i magia życia pozostają nietknięte.

Oglądany z lepszej perspektywy naszego zachodniego stadium rozwoju, amerykanizm jawi się jako próba skoordynowania wszystkich sił społecznych w nowoczesnym kształcie, przy tym czyni to, ustanawiając jednowymiarowy cel ekonomiczny, co działa przeciwko ludzkim umysłom, ich potencjałowi krytycznego myślenia i zdolności do sprzeciwiania się [„,Von der höheren Warte unserer abendländischen Entwicklung gesehen, erscheint der Amerikanismus geradezu als ein Versuch, die Zusammenfassung aller gesellschaftlichen Kräfte in moderner Form zu verwirklichen - und zwar durch eine gegen den Geist und seine stets wachen Bedenken gerichtete, einseitig wirtschaftliche Zwecksetzung"].

Wariacje na temat głównego motywu mechanizacji i ekonomicznej racjonalizacji - jako zagrożeń dla europejskiego ducha - rozwijali też inni niemieccy autorzy. Raz za razem wykorzystywano cały metaforyczny repertuar antyamerykanizmu. Z artykułu Richarda Müllera-Freienfelsa Der deutsche Gedanke z 1927 roku jasno wynika, że dla autora niebezpieczeństwo przeniesienia amerykanizacji do Europy leży nie tyle „we wprowadzeniu amerykańskiej mechanizacji jako takiej” (,in der Einführung amerikanischer Maschinen ans ich”), ile „w zniwelowaniu duchowości, co wydarzyło się w samej Ameryce” (,in der Nivellierung des Geistes, die diese in Amerika selbst gezeitigt haben”). Autor wyróżnia ogólny 
amerykanizm jako rozwojową fazę, której doświadcza także Europa, i bardziej określony amerykanizm, któremu Europa miałaby się sprzeciwić. Jako elementy tego drugiego, oprócz duchowego zrównania, postrzega bezmyślną pogoń za każdym nowym rekordem, ubóstwianie sportu, sprowadzenie człowieka do funkcji maszyny. To jest to, co Europa powinna odeprzeć; w opozycji do tego Europa musi zaakcentować „wartość, jaką wiąże z jakością przeciwnie do ilości, z życiem organicznym zamiast z mechanizacją, z osobowością, a nie z konformizmem" („ihre Wetung der Qualität gegenüber der Quantität, organisches Leben gegen Mechanisierung, Persönlichkeit gegen Nivellierung").

Inny ówcześnie żyjący Niemiec, filozof hrabia Hermann Keyserling, holista w tradycji Carla Junga, doszukiwał się krytyki zmechanizowanego społeczeństwa przede wszystkim w idealnym typie człowieka w całej jego okazałości. Ale on także, zwłaszcza w dziele Amerika: Der Aufgang einer neuen Welt (we Francji wydanym jako Psychanalyse de l'Amerique i mającym wplyw na tamtejszy wizerunek Ameryki), w istocie powiązał ogólniejszą krytykę kultury z Ameryką. Podobnie jak Huizinga, Keyserling uciekł się do retorycznego podstępu, aby utrzymać Amerykę na dystans. Dostrzegł istnienie wśród Amerykanów wrodzonego socjalizmu, wiążąc go z faktem, iż „społeczne skłonności rzeczywiście dominują w amerykańskiej duszy” („die sozialen Tendenzen in der amerikanischen Seele wirklich vorherschen"). Świadczą o tym amerykańskie ideały, takie jak „normalność”, „jednomyślność” i „standardy”. Jednak w rzeczywistości stanowi to powrót $\mathrm{z}$ wyższego na niższy poziom rozwoju cywilizacji. Biorąc pod uwagę ich sposób myślenia, który ogranicza się do poziomu „ledwie wykrywalnego intelektu” („dem Intellekt erfaszbare”), praktycznej inteligencji i zdrowego rozsądku, Amerykanie nastawieni są ku przyszłości, mają jednak tendencję do ignorowania „nierozerwalnych więzów pomiędzy przeszłością, teraźniejszością i przyszłością”(,unzerreiszbare Zusammenhang von Vergangenheit, Gegenwart und Zukunft"). Wizerunek człowieka w Ameryce odzwierciedla się w pojęciach mechanizacji i fizycznej kontroli nad światem. W psychologii behawioralnej - według Keyserlinga jest to typowo amerykański pogląd na człowieka - istoty ludzkie zachowują się jak zwierzęta, jak szczury biegające w kołowrotku. Wszystkie ludzkie zachowania mogą zostać zredukowane do nabytych, ustalonych zwyczajów, które z kolei mogą być postrzegane jako w pełni zdeterminowane przez czynniki zewnętrzne i tym samym otwarte na zewnętrzną manipulację i kontrolę. Zatem Amerykanin jawi się jako gatunek dobrze czujący się w świecie komercji, mechanizacji, manipulacji poprzez reklamę, w świecie racjonalnej organizacji. Jest on doskonałym trybikiem w perfekcyjnej maszynie.

Musimy poczynić tu jeszcze jedną uwagę. W argumentach podsumowanych powyżej widać niezwykłą spójność, do tego stopnia, że trafność zdaje się być wzmacniana przede wszystkim przez powtarzanie ich w nieskończonych wariantach. Jednak ten sam dyskurs wypowiadany przez innych autorów może nagle ukazać się w innym świetle. To, co dotąd zaobserwowaliśmy w przypadku 
Europejczyków, którzy mieli skłonności do łączenia Ameryki z laickimi trendami mechanizacji i industrializacji, było też gotowością do przyznania amerykańskiej organizacji ekonomicznej, racjonalności i sprawności. Jak to ujął Huizinga: „Ta wasza doskonała organizacja...”. Istnieją jednak także przykłady ilustrujące przeciwstawny pogląd. Rozważmy przypadek H. G. Wellsa, który po przyjeździe do Nowego Jorku stwierdził: „Hałas i ludzki pośpiech, i bezmiar sposobów, i ich wspólnotowy rezultat zamiast ogromu sukcesu jest cechą przenikającą Nowy Jork. Wspaniałą rzeczą jest rzecz mechaniczna, mimowolna rzecz, która napędza tych wszystkich ludzi...” Dzień później pisal, że „nadal utrzymuje się wrażenie niezmiernie potężnego ruchu naprzód i potrzeby szybkiego rozwoju", ale po dobrze przespanej nocy był już skłonny napisać także, iż „ludzka istota znaczy mniej niż rozgnieciona mucha”. Był więc w stanie wyraźniej dostrzec element ludzkiego rozwoju i kwestię kontroli, a więc zbiorowe ćwiczenia woli w tym, co zaledwie dzień wcześniej uderzyło go jako „mechaniczna rzecz, mimowolna rzecz". Obraz zmechanizowanego świata, bez sensu lub celu, w ciągłym ruchu, w końcu też poza „ogromem sukcesu”, może nam przypominać Henry’ego Adamsa, który niemal w tym samym czasie projektował na amerykańską scenę swoją metaforę entropii. A jednak Wells był ulepiony z innej gliny. Był socjalistą, który sądził, że przyszłość leży w gigantycznej technice udostępnianej równie gigantycznemu kolektywnemu duchowi przedsiębiorczości. Sentymentalizm i nostalgia były mu obce. Nad wodospadem Niagara najbardziej zachwyciły go elektryczne turbiny: „To one są unaocznieniem woli, myślą przemienioną w rzeczy proste i majestatyczne”. W Bostonie wreszcie odnalazł to poczucie celu, planowania i przewidywania, zastosowane do rozwiązania problemów gwałtownej urbanizacji. Swoją wycieczkę po mieście opisał jako eksplorację „świeżej i dość rozmyślnej fazy tej znakomitej amerykańskiej symfonii, symfonii Wzrostu”. Wzrost go ekscytowal, „mechaniczne rzeczy” wprawiały go w ekstatyczny szał, o ile towarzyszył temu „namysł”, intencjonalność. W tym sensie było mu bliżej do entuzjazmu głoszonego przez Amerykański Ruch Postępu (Progressive Movement in America) niż do poczucia wydziedziczenia i alienacji, które charakteryzowały estetów takich jak Henry Adams i Henry James ${ }^{8}$.

Zatem mechanizacja i jej oddziaływanie na kulturę mogły być widziane z zupełnie różnych perspektyw: jako zagrożenie dla tradycji i indywidualności, zwłaszcza we Francji; jako podkopywanie tak cenionych w Niemczech Volksgeist i Kultur, jako siła odnowienia, która przyniosłaby dobrobyt i wolność (w opinii przywódców związków zawodowych i socjalistów w wielu europejskich krajach); i wreszcie jako nosicielka nowej estetyki, piękniejszej niż wodospad Niagara. Jak

8 H. G. Wells, The Future in America: A Search After Realities, Bernard Tauchnitz: Leipzig 1907, s. 42. 
zobaczymy, debata o nowych formach mechanicznej sztuki, takich jak fotografia i film, wykorzystywała te różnorodne perspektywy. Ale z którejkolwiek strony podejmowana była debata, Ameryka pozostawała punktem odniesienia.

\section{Film, Hollywood i Holandia: lata międzywojenne}

Recepcja amerykańskich filmów w Holandii i krytyczna eksploracja ich amerykańskości przebiegały na różnych poziomach, ujawniając rozmaite dyskursy krytyczne, które charakteryzowały każdą z wielu samozwańczych społeczności obrońców kultury. Jedna z takich społeczności skupiała swój dyskurs wokół estetyki filmu jako nowej formy sztuki. Grupa filmowców i krytyków filmowych założyła stowarzyszenie Film Liga. Ich celem było opracowanie zestawu kryteriów estetycznych, które pomogłyby definiować film jako poważną, autonomiczną formę sztuki w obliczu rozpowszechnionego pogardliwego spojrzenia na to medium jako wehikułu zwykłej, masowej rozrywki. Debata w środowisku elity kulturalnej - nastawiająca młodsze pokolenie kulturowych buntowników przeciwko strażnikom ugruntowanych poglądów na „kulturę wysoką” - zmusiła adwokatów filmu jako nowej formy sztuki do odpowiedzi na argumenty i do określenia własnego stanowiska względem zalewu produkcji amerykańskiego przemysłu rozrywkowego. W pewnym sensie odzwierciedlali oni hierarchiczne poglądy swoich oponentów: ich własna krytyczna perspektywa estetyczna również koncentrowała się wokół porównania wysokiego i niskiego, wulgarnego i wysublimowanego, a więc wokól tego, co doprowadziło ich polemistów do odrzucenia filmu w ogóle. Do tego stopnia, że sami rozwinęli krytyczny język, aby wyplenić to, co niskie, z odnoszącej sukcesy produkcji filmowej. Film amerykański był ich typowym celem. Krytyka jego komercyjnego charakteru, systemu studyjnego, fenomenu gwiazd filmowych i przemysłowej standaryzacji produktu ujawniała nie tylko ich estetyczne obawy, ale także zestaw - powszechnych wśród europejskich elit kulturalnych - uprzedzeń wobec kultury amerykańskiej.

Pojawiały się także inne reakcje obrońców kultury, tym razem skupiające się bardziej na kryteriach moralnych niż na estetyce. W różnorodności holenderskiego krajobrazu kulturowego, z jego podzielonym wzorem wyznaniowym i obyczajowo-politycznymi blokami, każda grupa rozwijała swój własny język w rozpoznawaniu zgubnego wpływu filmu jako nowej formy masowej rozrywki. Była to tylko jedna z praktyk w kontekście szerszych kampanii kulturowych. Przeciw nowym formom rozrywki - wprowadzonym przez nową kulturę konsumpcji i będącym poza opiekuńczym zasięgiem każdego ze społecznych bloków - każda grupa próbowała rozwinąc intensywną i edukacyjną formę wypoczynku, czerpiąc na przykład z repertuaru ludowego czy skupiając się na aktywnościach fizycznych na świeżym powietrzu, pomyślanych tak, żeby trzymać młodzież pod stałym nadzorem kulturowym. W tym, co tak naprawdę było kolektywną refleksją nad 
wydolnością moralnie kojących form kultury popularnej, po raz kolejny możemy dostrzec szersze poglądy na wpływ amerykańskiej kultury masowej na dyskusję o amerykańskich filmach.

\section{Film Liga - estetyka kontra komercjalizacja}

W Holandii w okresie międzywojennym obrona filmu jako nowej formy sztuki zawsze służyła do równoczesnego promowania innych celów. Każdy z nich na swój własny sposób nadawał debacie ton niecierpliwości, oferując dyskusji szersze znaczenie $\mathrm{w}$ walce o przetrwanie kultury lub nawet jej odnowienie. Jednym z kontekstów bojowej tezy był głos początkującego pokolenia młodych intelektualistów, próbujących przebić się przez ograniczenia ustanowionych dyskursów kulturowych. Eksplorowanie przez nich ekspresywnego potencjału filmu było częścią szerszego badania nowych metod wyrazu i nowej estetyki w wieku, w którym ustanowione kanony sztuki zostały nieodwracalnie rozbite przez wojnę, rewolucję i masowe przemiany społeczne. Ci, którzy uważali się za członków międzynarodowej awangardy, jak na przykład Theo van Doesburg - założyciel czasopisma poświęconego sztuce współczesnej, „De Still” - powitali film jako medium zdolne do zaprzęgnięcia współczesnej techniki do służby w imię pomysłów na „nowe obrazowanie” (nieuwe beelding), czyli „neoplastycyzm”. Włączenie przez van Doesburga filmu w ramy ogólniejszych poglądów estetycznych awangardowych, antyburżuazyjnych i antynaturalistycznych - nie zawsze bywało akceptowane przez innych reprezentantów jego pokolenia, podzielali oni jednak pilną potrzebę wypracowania krytycznego języka, który oddałby sprawiedliwość filmowi jako nowej formie sztuki. Powrócimy do nich na dłużej nieco dalej.

Drugie powszechne twierdzenie, często implicytnie zawarte w krytycznych tekstach o filmie, było nie tyle związane z młodszym pokoleniem narzucającym swoje poglądy na kulturę, ile z potrzebą umocnienia tożsamości kulturowej wobec niszczycielskich sił. W tym drugim przypadku nacisk położony jest bardziej na przetrwanie kultury niż na jej odnowienie. Jednak te dwa cele nie wykluczają się wzajemnie. Wielu przedstawicieli zarówno młodszego, jak i starszego pokolenia argumentowało równolegle - w obronie cenionej, ale zagrożonej tożsamości kulturowej oraz na rzecz radykalnej redefinicji estetyki. Zatem byli w Holandii ludzie tacy jak Johan Huizinga i Menno ter Braak, reprezentanci dwóch różnych pokoleń, dyskutujący nad kwestią obrony kultury w imię „Europy” przeciwko „Ameryce”. Później ter Braak - jako młody buntownik - będzie poszukiwał nowej estetyki filmowej. Walczył zatem na dwóch frontach jednocześnie. Ale tak samo zrobił Huizinga, aczkolwiek z mniejszym wigorem ze względu na wiek i temperament.

9 T. van Doesburg, Lich ten tijdsbeelding (film), „De Still” 1923, no. 6, s. 5 i 62. 
Poglądy Huizingi na film są charakterystycznie ambiwalentne. Odwzorowują jego mieszane odczucia wobec Ameryki. Z jednej strony w swojej kolekcji podróżniczych wrażeń z 1927 roku doszedł do akceptacji filmu jako sztuki, dla której powinna się znaleźć nowa muza lub święty patron. $\mathrm{Z}$ drugiej strony jednak łagodzi też swoją postawę, wskazując że movies - jak je określił w holenderskim tekście - są zaledwie ilustracjami, jakkolwiek najważniejszymi, złowieszczej przemiany naszej cywilizacji: od czytania do oglądania, od słowa drukowanego do informacji „ideograficznej”. Zarazem jednak Huizinga był ambiwalentny. Rozmyślając nad wpływem filmu, którego doświadczył w Ameryce, był świadomy demokratycznego potencjału tego medium. Film był jak styl Walta Whitmana ze zdolnością do odświeżenia demokratycznej perspektywy, pozwalając ludziom na pełny, lecz zapośredniczony ogląd różnorodności życia w społeczeństwie. Jednocześnie bardziej pesymistyczne poglądy Huizingi na mechanizację współczesnej kultury zakłócały te wielkie nadzieje. Jako jedno z nowych mediów masowych, film, podobnie jak radio, skierowany był do masowej publiczności, odpowiadając jej przeciętnemu gustowi. Miał tendencję do upraszczania i stereotypizowania przekazu. Mógł rozszerzyć ludzkie poglądy na społeczeństwo, ale tylko fałszywie, przez schlebianie społecznemu i kulturowemu krajobrazowi.

[Film] wdraża cały naród - od wysokich stanów do niskich - do jednego wspólnego poglądu na życie. Ze względu na ograniczone środki wyrazu, na podkreślanie tego, co zewnętrzne oraz z powodu konieczności przypodobania się szerokiej publiczności, film wyłącza cale wielkie obszary duchowej aktywności. Narzuca ograniczoną ilość standardowych opinii o życiu, które w końcu staną się masowym poglądem ${ }^{10}$.

Tak więc film był jedną z działających w Ameryce współczesnych sił kulturowej erozji. Jako odmiana sztuki, choćby nawet wizualna, nigdy nie wykreowałby trwałych, samodzielnych form, takich jak rzeźba czy malarstwo. Nie ma u Huizingi żadnych marzeń o „neoplastycyzmie”. Ze swoją narracyjną płynnością film był dla niego bardziej jak literatura czy dramat. Zarazem film był nastawiony na masowy rynek, podobnie jak radio, mógł więc zniewalająco przykuć uwagę swojej publiczności, ale tylko przejściowo, na ulotne momenty. W przeciwieństwie do dramatu czy literatury, nigdy nie mógłby spowodować, by publiczność zatrzymała się i oddała się refleksji.

Pomimo sprzecznych odczuć, jakie Huizinga mógł mieć wobec filmu, zdołał on jednak przenikliwie zdefiniować wewnętrzną siłę medium w sposób, który do dzisiaj inspiruje krytyczną refleksję o filmie. Nawet teraz akademickie badanie filmu jest źródłowo uwikłane $\mathrm{w}$ intrygującą wymianę pomiędzy wyobrażonym światem srebrnego ekranu a poczuciem tożsamości jednostek, które nań patrzą.

${ }^{10}$ J. Huizinga, Denkend Mensch en Menigte..., s. 28. 
Proces identyfikacji z cieniami pojawiającymi się na ekranie prowadzi publiczność do wyjścia poza siebie. Huizinga poczynił w tym temacie następującą obserwację:

[Film] pokazuje mieszkańcowi miasta sielskie życie, a przynajmniej jego wyobrażenie; pokazuje też mieszkańcowi wsi życie miejskie, daje biednym pogląd na luksus, a bogatym na nędzę, wszystko bardzo stylizując dla ułatwienia odbioru. Film działa więc tak, by łagodzić, a nie zaostrzać klasowe urazy. Powtarzana iluzja życia zamożnych pozwala biednym dzielić wspólnotę luksusu i wyrafinowania, których fantazyjne wyobrażenie staje się częścią ich codziennej egzystencji. Publiczność dowartościowuje się poprzez bohatera, a poza tym ekranowe gwiazdy filmowe oferują nowy model naśladowania, nowatorskie zapewnienie o możliwościach dostępnych dla wszystkich... ${ }^{11}$

Oczywiście, są to idiosynkratyczne poglądy jednostki. Są one swobodnymi rozważaniami człowieka, który nigdy nie był istotnie zaangażowany w intensywną debatę o filmie. Mimo to, jako ważny krytyk kultury, Huizinga czytelnie odwoływał się do społecznych i kulturowych trendów, które służyły jako rama dyskusji o kwestiach podniesionych przez młodsze pokolenie. Jednak, inaczej niż on sam, wielu młodszych i współczesnych mu odrzuciło typową ostrożność i ambiwalencję. Mieli skłonność do obwieszczania nadejścia nowych form sztuki, jak film czy fotografia, które wykorzystywały techniki mechanicznej reprodukcji w celu zdobycia masowej publiczności. Tam gdzie w mechanizacji kultury Huizinga dostrzegał napięcie pomiędzy obietnicą demokratycznej sztuki a jej fałszywą realizacją w kulturze masowej, obrona filmu przez młodsze pokolenie koncentrowała się na technicznych warunkach produkcji filmowej. Jeśli film dotrzymałby obietnicy, byłby to dla nich jeden z przywróconych sojuszy pomiędzy światami wynalazków technicznych i kreacji artystycznej, pomiędzy kulturą a maszyną, które od tak dawna były od siebie odłączone. Podczas I wojny światowej maszyna objawiła światu europejskiej kultury swój destrukcyjny potencjał. Ale w tym samym czasie, wśród zbiorowego wysiłku walczących, pojawiła się nowa wizja maszyny jako zwiastuna nadchodzącej cywilizacji technicznej. Intelektualiści, pozostający w rolach strażników i krytyków kultury, nie mogli dłużej pozwolić sobie na ignorowanie nowego poczucia euforii, wynikającego z niespokojnej prędkości i energii, jakie spowodowała technika. Również dla nich film był nowym medium idealnie nadającym się do przekazania tej nowej świadomości egzystancjalnej. Zamiast odrzucać film jako techniczną zabawkę niezdolną nigdy do dostarczenia czegoś więcej niż tylko płytką rozrywkę dla mas oraz zamiast kontynuować fałszywy podział między intelektualnym obszarem kulturalnego życia i przyziemnym królestwem inżyniera, pokolenie młodszych intelektualistów uczyniło film

11 Ibidem. 
obiektem refleksji krytycznej. Byli świadomi tego, że film jeszcze nie wykorzystał w pełni swojego artystycznego potencjału. Ich odpowiedzialnością, jak to widzieli, było krzewienie nowo powstałej formy sztuki, tworzenie nowego krytycznego języka, doskonalenie nowej estetyki i edukowanie szerszej publiczności.

Ich walka rozgrywała się zawsze na więcej niż jednym froncie. Istniał aspekt walki pokoleniowej - młodszego pokolenia przekornie rzucającego wyzwanie formom dyskursu dominującym na rynku idei. Podczas gdy Huizinga i jego pokolenie oraz inni myślący w ten sam sposób nadal mieli tendencje do trzymania się dychotomicznego, jeśli nie manichejskiego, poglądu na życie umysłowe w zmechanizowanym świecie, wielu z młodszego pokolenia całkowicie zaadaptowało maszynę jako potężny składnik współczesnej kultury. Ta druga postawa miała raczej podłoże pokoleniowe, nie zaś ideologiczne. Niezależnie od politycznych podziałów, wszędzie odnajdujemy młodych autorów broniących film przed wieloma krytykami.

Zatem na przykład w „Communisme” - teoretycznym czasopiśmie Holenderskiej Partii Komunistycznej - można znaleźć opinię G. de Walla przemawiającego za stanowiskiem, które bez wątpienia było poprawne politycznie, ale jednocześnie zostało odczytane jako bardzo oryginalna obrona przemysłowej produkcji filmowej. Przeciwko wszystkim tym, którzy orzekli, że film jako sztuka został skazany na industrializację i standaryzację tworzenia, dowodził on, że przemysłowa produkcja na dużą skalę to jedyny tryb zgodny z dominującymi siłami wytwórczymi. Przeciwko elitarystom, których ulubione filmy powstały dla kilku szczęśliwców w małych warsztatach i pracowniach, użył w zasadzie tych samych argumentów, wskazując, że ich poglądy reprezentują przestarzały etap rozwoju. Jego zdaniem to nie sposób produkcji był niewłaściwy, ale jej kapitalistyczne dążenia. Stojąca za produkcją filmową chęć zysku sprawiła, że film nie mógł wykorzystać w pełni swojego potencjału ${ }^{12}$.

Inni, niekoniecznie mający tak lewicowe poglądy, byli równie optymistyczni w kwestii postrzegania filmu jako mechanicznej sztuki. Tak więc Leendert Jurriaan Jordaan, socjalista i jeden z pierwszych „filmowych” intelektualistów w Holandii, widział technikę jako kluczową cechę swoich czasów. Miała ona głęboki wpływ na warunki codziennego życia, a mimo to była ignorowana jako obiekt refleksji kulturowej. Film doskonale ucieleśniał ducha epoki techniki i podobnie jak technika miał się zakorzenić na stałe. W tekście pełnym batalistycznych metafor - i wymownie zatytułowanym Walka o srebrny ekran ${ }^{13}$ - Jordaan wzywał intelektualistów, by potraktowali film poważnie i za pośrednictwem prasy dostarczyli

12 G. de Waal, De ontwikkeling van de filmkunst in de kapitalistische maatschappij I, „Communisme” 1926, 2 April; De ontwikkeling van de filmkunst in de kapitalistische maatschappij II, „Communisme” 1926, 2 juni.

${ }_{13}$ L. J. Jordaan, De strijd om het witte doek, „NU” 1927, 1 oktober, s. 71-75. 
krytycznych wskazówek szerokiej publiczności. Forum, które Jordaan wybrał dla swojego apelu, było krótko żyjącym pismem „NU” („teraz”), które, podobnie jak dziesięć lat wcześniej w Stanach Zjednoczonych „The Seven Arts”, miało być wezwaniem do ożywienia i odmłodzenia życia kulturalnego. Jak ujął to jeden $\mathrm{z}$ dwóch redaktorów pisma, socjalista Adrianus Michiel de Jong, we wstępie do pierwszego numeru, sztuka nie może już być prywatnym dziełem jednostki: „Braterstwo jako dewiza nowych czasów odbija się echem na całym świecie. To wezwanie młodej, gorliwej rasy, gotowej na każde poświęcenie, nie dla swojej własnej wielkości, ale w imię wspólnego dobra' ${ }^{14 ”}$.

Chociaż starcie generacji było jedną z powracających cech debaty na temat filmu, zawsze obecny był też drugi plan bitwy. Gdy celem była obrona filmu jako nowej formy sztuki, wówczas potrzebowała ona negatywnego układu odniesienia oraz nowego krytycznego języka i nowej estetyki (dla właściwego docenienia medium na jego własnych zasadach, aby wyemancypować je spod dominacji starszych form sztuki). Liczni z wczesnych zwolenników filmu zgadzali się, że stosowna obrona zmusza do dezawuowania jego niskich, przeznaczonych dla masowej rozrywki form. Implicytny elitaryzm przekształcił się w polemiczne odrzucenie „amerykanizmu”. Tę postawę dzielili z wieloma przedstawicielami starszych krytyków kultury, co pozwoliło zbliżyć pokolenia dotychczas trzymające się $\mathrm{z}$ dala od siebie.

Zatem Jordaan w cytowanym wyżej artykule zaznacza, że walka o srebrny ekran (,jeden z najbardziej naglących problemów naszego czasu - problem TERAZ!”) nie oznaczała tylko potyczki z zewnętrznymi przeciwnikami, lecz powinna być także rozumiana jako wewnętrzna czystka.

Oznacza to, oprócz wielu pozostałych kwestii, walkę przeciw „amerykanizmowi” - przeciw bezsensownemu i bezmyślnemu zaszczepianiu nijakości, infantylnej mentalności oraz przeciwko powodzi energii kultury młodej, dopiero co wprowadzonej na rynek, zalewającej nasz stary, doświadczony i umęczony stan umysłu $^{15}$.

W późniejszym wydaniu „NU” Jordaan jeszcze raz podejmuje ten motyw, czyniąc go swoim głównym argumentem. Tekst nosi tytuł Amerykanizm i film:

My, dzieci starej Europy, nie przepadamy za Amerykanami. [...] Nie lubimy ich, ponieważ przeciwko nim buntuje się to, co w nas najlepsze: nasza kultura i nasza tradycja. [...] Dla nas ten biały brat „skądś tam” pozostaje hałaśliwym, ograniczonym, zarozumiałym, aroganckim i bardzo wulgarnym nowobogackim. Ogólnie jest to krewniak, któremu życzymy jak najlepiej, dopóki się nam nie narzuca. Właśnie to - co przykro nam mówić - przez ostatnie lata działo się poprzez film.

14 A. M. de Jong, Ter inleiding, „NU”1927, 1 oktober, s. 8.

15 L. J. Jordaan, De strijd om het witte doek..., s. 73. 
Gdy film „w jego szlachetniejszych formach” - nie trzeba dodawać, że Jordaan ma tu na myśli kinematografię niemiecką, francuską i rosyjską - zaczynał zdobywać uznanie pośród lepiej wykształconych klas społecznych i stawał się sam w sobie kulturalną potęgą, amerykański przemysł filmowy osiągnął pozycję hegemona kontrolującego światową produkcję filmową. W rezultacie mentalność, choć „made in America”, zaczęła być eksportowana ogólnoświatowo. „Teraz jest to zgubne, absurdalne, nie do przyjęcia!”. Jeśli Europa to dom, „stary, być może zagrzybiały, lecz szacowny", rozświetlony blaskiem Rembrandta, Bacha, Beethovena, Dantego i Szekspira, to zostaje on najechany przez obcego, „który bezwstydnie przypina na ścianach obrazki ślicznotek z opakowań po mydłach i wypełnia pokój rykiem charlestona oraz dirty-dig." Jednak nie tylko masy byly przetrzymywane w niewoli i zamknięciu przez „chroniczne masowe zatrucie”. Również intelektualiści interesujący się filmem musieli przezwyciężyć ten potop ${ }^{16}$.

Głos Jordaana był jednym z mniej subtelnych w chórze przeciwników amerykanizmu w latach 20 . Na początku 1925 roku miesięcznik literacki i kulturalny „De Stem” przeprowadził ankietę dotyczącą poglądów holenderskich intelektualistów na temat filmu. Wydawcy narzucili wymowę badania, nazywając film niegodziwą wiedźmą, „opuchniętą przez wszelkie złe soki naszej cywilizacji”. Jak nietrudno się domyślić, pojawiło się wiele krytycznych odpowiedzi, kładących nacisk na mechaniczność, naturalizm i standaryzujące cechy filmu. Głównym winowajcą były filmy amerykańskie. Młody poeta Slauerhoff gotów był dać nowemu medium szansę pod warunkiem, że przez najbliższe dwadzieścia pięć lat import tytułów ze Stanów Zjednoczonych zostanie wstrzymany. W tym samym 1925 roku podczas konferencji podejmującej „problem kin” - zorganizowanej przez VCSJ, chrześcijańską organizację młodzieżową - H. C. Verkruysem, dyrektor szkoły artystycznej w Harleemie, zanegował możliwość, aby film mógł kiedykolwiek stać się formą sztuki. Również jego argumenty były skierowane głównie przeciw filmom amerykańskim ${ }^{17}$. W 1927 roku manifest Amsterdamskiej Ligi Filmowej napisany przez jednego z jej członków założycieli, J. Scholte’a, zakładał, że „raz na sto przypadków oglądamy film, poza tym oglądamy same filmidła. Ten tabun, komercyjny reżim, Amerykę, kicz". Inny wspóltwórca Ligi, Menno ter Braak, również miewał mniej subtelne wypowiedzi. W tekście, który napisał jako redaktor „Propia Cures”, satyrycznego tygodnika dla amsterdamskim studentów, swoim jednoczącym zawołaniem uczynił hasło „Europa dla Europejczyków!”. $\mathrm{Z}$ prawdziwie walecznym zapałem nawoływal, by do ostatniego tchu bronić kultury starej Europy. „Umysł obdarza życiem, amerykanizm zabija [...] Amerykanizm przemienia człowieka w bezmyślną maszynę, podczas gdy pieniądz się mnoży.

${ }^{16}$ Idem, Het Americanisme en de film, „NU” 1928, no. 1, s. 418-422.

${ }^{17}$ Jaarboek Media Geschiedenis, Stichting Mediageschiedenis: Amsterdam 1989, s. 75. 
Przenika wszystko, przeżera wszystko, deprawuje wszystko aż do samego środ$\mathrm{ka}^{18}$. W 1930 roku, pracując jako krytyk filmowy w jednym z najważniejszych holenderskich dzienników, ter Braak napisał artykuł zatytułowany „Amerykanizm" $w$ świecie filmu ${ }^{19}$. Tym razem ton jest spokojniejszy, ale osąd równie surowy. Jego zdaniem jedynym trwałym osiągnięciem amerykańskich filmów - naiwnie nieświadomych konkurencyjnych form sztuki i produkowanych po prostu dla masowej rozrywki - było ich zetknięcie się z podstawowymi zasadami kinematografii, „podczas gdy Europejczycy wciąż niezdarnie trenowali stosowanie obiektywów w Comédie Française lub pokładali nadzieje w niezwykle ekspresyjnych dekoracjach". Bez naiwności Amerykanów (ter Braak przedstawia ich niemal jako szlachetnych dzikusów), bez ich braku wewnętrznego rozdarcia, film jako sztuka „tak bliska bardziej skomplikowanym Europejczykom, był skłonny ukształtować się na podstawie pozostałych form sztuki”. Jednak dla dalszego rozwoju poważnej kultury filmowej Ameryka stała się obciążeniem. A dokładniej nie Ameryka, lecz amerykanizm. Amerykanizm jako mentalny nawyk znacząco przekroczył geograficzne granice konkretnego kraju. W samej Ameryce, w ramach dalece rozwiniętej standaryzacji produkcji filmowej, „mogło to osiągnąć najbardziej przerażające apogeum, jednakże jako mentalność może znaleźć się wszędzie”. To mentalność „ogólników, truizmu”.

Czymś nadzwyczajnym w całej tej gorączkowej „nobilitacji” kultury amerykańskiej jako głównego zagrożenia dla wszystkiego, co autorzy uważali za sobie drogie, nie był w rzeczywistości kulturowy instynkt przetrwania. Chodzi tu raczej o język, w jakim wyrażali główne ramy konfliktu. To nie holenderska kultura była zagrożona amerykanizmem, lecz kultura europejska, europeizm. Jest w tym wiele ironii. Jeśli jednym z najbardziej potężnych efektów przeciwstawienia się amerykańskiej kulturze była reaktywacja szeregu narodowych dyskursów w Europie - wykorzystujących jako punkt odniesienia Europę raczej niż różnorodne narodowe konteksty - to europejscy krytycy Ameryki mają za co jej dziękować. Obecnie ten fakt jest zazwyczaj pomijany.

Nie tylko mniejsze kultury narodowe miały skłonność do formułowania krytyki Ameryki z pozycji ogólnoeuropejskich, choć w ich przpadku mogło zdarzać się to częściej. Również wśród przodujących krytyków amerykanizmu w Niemczech czy Francji najważniejszą opozycją była ta pomiędzy Ameryką a Europą. Jednak - i tym razem nie bez ironii - widzimy, że na Europę przywoływaną w pismach francuskich (chociażby przez Duhamela lub André Siegfrieda) albo niemieckich (na przykład Oswalda Spenglera, Halfelda czy Keyserlinga) zawsze pada charakterystyczne francuskie bądź niemieckie światło. Francuscy autorzy

18 M. ter Braak, De Propria Cures artikelen, Amsterdam 1978, s. 216-217.

19 Idem, “Americanisme” in de filmwereld, „Nieuwe Rotterdanische Courant” 1930, 15 februari. 
zwykli projektować na szerszy europejski ekran typowe francuskie obrazy indywidualizmu, aby podkreślić kontrastującą z nim amerykańską standaryzację produkcji, która trafiła w przeciętne gusta mas. Z kolei niemieccy autorzy argumentowali w ramach kolektywnego „Ducha”, „Kulturvolku”, jako centralnego elementu definiującego cywilizację „Abendlandu”, a więc Zachodu. Według nich właśnie to konstytuowało europejską antytezę amerykanizmu.

Wizerunek Europy był przez tych pisarzy przedstawiany w charakterystyczny, narodowy sposób, a w dodatku „Europa” służyła im jako nietrwała fasada retoryczna. Bardzo często nie mogła ona zamaskować pęknięć pomiędzy odmiennymi kulturami narodowymi. Zabawny przykład takiej praktyki można znaleźć w tekstach André Siegfrieda. W 1927 roku napisał on przedmowę do rozprawy André Philipa na temat kondycji klasy robotniczej w Ameryce Le problème ouvrier aux Etats Unis. Wywód dotyczy miejsca pracowników w przemyśle, który został zorganizowany zgodnie z założeniami fordyzmu, tayloryzmu, standaryzacji, masowej produkcji i przede wszystkim „maszynizmu” (le machinisme). Siegrfried wychwala Philipa jako „zacnego Europejczyka” (bon européen), który wyruszył ocenić warunki pracy amerykańskich robotników wedle miary europejskich wartości humanistycznych. Przypomina też, jak sam dopiero w Ameryce zorientował się, że „europejski świat stanowi integralną całość” („le monde européen comme un ensemble").

„Dopiero tam można nabrać świadomości, że jest rzeczywistość, która nam umyka, a mianowicie, że istnieje europejski umysł oraz amerykański umysł stanowiący dla niego niejednokrotnie perfekcyjną antytezę” („on prend conscience d'une réalité qui nous échappe ici, c'est qu'il existe un esprit européen, dont l'esprit américain est souvent la parfaite antithèse"). Z moralnego punktu widzenia Ameryka w swojej obecnej postaci została odcięta od dwóch tysięcy lat naszej tradycji przez lukę wywołaną emigracją za ocean. W rezultacie nie łączy jej już wiele ze starą Europą, wciąż pozostającą w jedności z Rzymem, Grecją, a nawet Indiami. Do tego momentu Siegfried wyraźnie pojmuje Europę jako integralną całość („comme un ensemble”). Jednak niedługo potem zaczyna dodawać do swojego wyobrażenia dystynktywny szczegól: „spośród Europejczyków Francuzi mają największą świadomość tego, co ustanawia jednostkę, pojedynczego człowieka” („Parmi les peuples européens, le français est celui qui a eu, le plus, la conscience de ce qu'est un individu, un homme...”). Francja niewątpliwie zajmuje w europejskiej wspólnocie godne miejsce, ucieleśniając niektóre z rdzennych wartości europejskich, Siegfried idzie jednak dalej. Postanawia wytypować europejski kraj będący odpowiednikiem Ameryki - Niemcy.

Niemcy, tak podobni pod wieloma względami do współczesnych Amerykanów, zamotali się w standaryzację z tą samą pasją, z jaką podejmują się innych czynności; nie ma dziś Niemca, który nie wyśpiewywałby z przekonaniem hymnów na cześć „racjonalizacji”; wyraźnie koresponduje ona z ich geniuszem 
dyscypliny i - pozwólmy sobie to przyznać - ich brakiem osobowości („Les Allemands, al. Semblables à tant d'égards aux Américains modernes, se sont jetés dans la standardisation avec une sorte de passion, comme ils font toutes choses; il n'est point d'Allemand, aujourd'hui, qui ne chante avec conviction l'hymne de la 'rationalisation'; celle-ci répond évidemment à leur genie de discipline, avouons-le aussi, à leur manque de personnalité”).

To tyle na temat europejskiej wspólnoty.

Choć retoryczna fasada Europy mogła być powierzchowna, to pozostaje wart odnotowania fakt, iż w wielu europejskich krajach ludzie chcieli uwierzyć w swoją opozycję wobec Ameryki właśnie na takich zasadach. Tak czy owak, w każdym narodowym kontekście znajdujemy również odniesienia do przetrwania kultury narodowej i jej obrony. Jednak w Holandii jest ich zaledwie kilka, w dodatku odległych od siebie. W okresie kina niemego nie znalazłem żadnego przykładu. Gdy filmy zaczęły mówić, sztywne narodowe ramy debaty o kinie stały się bardziej czytelne. Film sam w sobie stracił transnarodowy charakter. Nie mógł już przekraczać barier językowych, jak miało to miejsce w przeszłości. Filmy musiały być dubbingowane lub zawierać napisy. Wszystkie większe europejskie kraje optowały za dubbingiem. Jako droższe z rozwiązań nie był on jednak komercyjnie atrakcyjny w mniejszych obszarach językowych. Jak na ironię, w Holandii dystrybutorzy przez krótki okres testowali pomysł wykorzystania wersji niemieckojęzycznych. Wskazywać by to mogło na brak świadomości zagrożenia dla języka i kultury Holandii. Co ciekawe, gdy w 1931 roku niderlandzki producent kronik filmowych, firma Polygoon, ogłosiła w Harleemie wprowadzenie do swoich filmów holenderskich ścieżek dźwiękowych, jej prezes D. Hamburger uznał tę okazję za wystarczająco istotną, aby osobiście pojawić się na ekranie. Z dumą oświadczył, że odtąd wykorzystywanie języka holenderskiego będzie ważnym narzędziem obrony przeciwko „szeregowi obcych prób naporu na język holenderski, za które w szczególności odpowiada amerykański film dźwiękowy”. W nieco późniejszym momencie tej dekady, w socjalistycznym miesięczniku „Socialisme en Democratie”, H. Brugmans recenzował holenderskojęzyczny film pełnometrażowy. Nie znalazł, co prawda, podstaw by go pochwalić, docenił za to samą próbę.

Bez wątpienia stworzenie własnego przemysłu filmowego leży w naszym interesie narodowym. Jest to rzecz oczywista, podobnie jak to, że przebicie się Francji przez amerykańską dominację było dobrodziejstwem dla artystycznego poziomu filmów wyświetlanych w Holandii. [...] niewątpliwie korzyścią będzie, gdy Holandia zyska pewną niezależność w tej dziedzinie ${ }^{20}$.

20 H. Brugmans, Nederlandse filmkunst, „Socialisme en Democratie” 1939, 7 april, s. 237. 
Z pewnością podobnych przykładów jest więcej, jednakże w debacie na temat filmu obrona suwerenności holenderskiej kultury jako takiej odegrała relatywnie małą rolę, zwłaszcza jeśli porównamy ją z gorącą dyskusją skoncentrowaną na niezależnej estetyce filmowej.

Ta druga sprawa może zostać podsumowana w następujący sposób: w ramach walki o niezależność estetyki filmowej grupa młodych entuzjastów z Holandii publikująca w wielu różnych miejscach, lecz skupiona przede wszystkim wokół Ligi Filmowej i jej periodyku prowadziła starcia na dwóch frontach jednocześnie. W ramach eksploracji nowego medium próbowali ukształtować kanon filmu czystego, przydzielając mu należne miejsce wśród pozostałych form sztuki. Jednocześnie byli też jednak zmuszeni bronić swojego kanonu przed siłami standaryzacji i przed rutyną produkcji filmowej, którą utożsamiali z amerykańskim przemysłem filmowym, czy też ogólniej: ze szkodliwym i wszechobecnym amerykanizmem.

Ich standardy były zazwyczaj przeintelektualizowane. Prowadzona na dwóch frontach walka o wyzwolenie medium ze stanu prymitywnych początków mogła czynić ich perspektywę otwarcie elitarną w podejściu do filmu jako medium masowego. Aż do późnych lat 20. niewiele amerykańskich filmów spotkało się $\mathrm{z}$ ich uznaniem; były one postrzegane jako wyjątki od ustabilizowanej - urzeczywistnionej przez zestaw Nibelungi (Die Nibelungen, 1924) Fritza Langa przeciwko Dziesięciu przykazaniom (The Ten Commandements, 1923) Cecila B. DeMille'a - opozycji „film europejski kontra amerykański”. Wśród recenzji Manna ter Braaka tylko jedna naprawdę docenia amerykańską produkcję, film Jazz (1925) Jamesa Cruze’a. Ponad dziesięć lat później w nekrologu szanowanego niemieckiego reżysera Waltera Ruttmanna, L. J. Jordaan przypomniał, że to właśnie Ruttmann podczas przemowy dla amsterdamskiej Ligi Filmowej zaskoczył wszystkich zebranych, otwarcie chwaląc film Cruze'a. Ruttmann jako „wielki innowator” mógł wypowiadać się na temat Hollywood bez często spotykanego gniewu, oddając honor nielicznym, którzy nigdy nie złamali swoich zasad w tej wspaniałej filmowej metropolii. Stopniowo w latach 30. krytycy filmowi zaczynali przyjmować coraz bardziej wyważony pogląd na filmy amerykańskie. Na przykład A. van Domburg w kolekcji esejów filmowych opublikowanych w 1936 roku jako jeden z pierwszych umieścił D. W. Griffitha wśród innowatorów awangardy filmowej, wskazując na kreatywne wykorzystanie przez niego montażu. Na nieco ogólniejszym poziomie, argumentuje van Domburg, europejscy twórcy i krytycy w swoich próbach chronienia filmu jako autonomicznej formy sztuki mieli w zwyczaju przesadnie odrzucać wszystko, co amerykańskie. Powodowana najlepszymi intencjami, ich awersja jest wprawdzie zrozumiała, lecz słabo uargumentowana. Istniała więc potrzeba nie tylko większego zrównoważenia, ale też całkowitego podwyższenia poziomu holenderskiej krytyki.

Zbyt rzadko dowiadujemy się, co czyni film dobrym i które z jego cech czynią go autonomiczną formą ekspresji; dlaczego film nie powinien zawierać serii 
fotografii, lecz raczej dynamiczno-rytmicznie uporządkowane ruchy i dlaczego ruch na ekranie nie ma nic wspólnego z filmem, podczas gdy ruch poza ekranem łączy z nim wszystko.

Pojawiają się tu echa wcześniejszych refleksji ter Braaka nad estetyką filmu, na przykład takie samo zastosowanie czasoprzestrzennych metafor zakorzenionych w muzyce i balecie (jako bliskich, aczkolwiek odmiennych formach sztuki). Niemniej nie znajdziemy tu już tonu wojowniczego manifestu. Rozmyślania van Domburga czyta się jak ogólnie zaakceptowane mądrości ${ }^{21}$.

Pomimo że poczucie konieczności prowadzenia bitwy wciąż trwało, zmieniła się linia konfrontacji. Jak określił to van Domburg, zwracając się do swoich katolickich współwyznawców w Holandii: „Generalnie, katolicka krytyka filmowa - w formie, w której objawia się w prasie - nadgorliwie skupiała się na moralnych aspektach kina”. Nie tylko pośród katolików, ale też wśród innych holenderskich społeczności połączonych wiarą czy filozofią, krytyczna reakcja na film wykształciła wyobrażenie filmu bardziej jako etycznego problemu niż jako obietnicy estetycznej. W istocie było to trzecim polem, na którym obrońcy filmu musieli działać. O ile do tej pory widzieli się w roli świadków zeznających w obronie filmu jako sztuki, teraz musieli spotkać się z oskarżycielami w innej sprawie. Jeżeli film był wciąż zagrożony, to bez wątpienia przez obrońców moralności, którzy dostrzegali w nim zagrożenie etyczne.

\section{Holenderski Verzuiling i amerykańskie filmy Debata na temat etyki}

W okresie międzywojennym w Holandii dokonał się proces segmentacji życia społecznego i politycznego, który rozpoczął się w późnym XIX wieku. Opisuje się go bardzo rozmaicie: jako reakcję na uprzemysłowienie i jego wykorzeniający wpływ na społeczność, jako reakcję na sekularyzację społeczeństwa, jako próbę przeciwstawienia się urokowi, który socjalizm wywierał na wyłaniającą się klasę pracowniczą albo jako odpowiedź na oczekiwanie na masową demokrację. $\mathrm{Z}$ pewnością była to reakcja $\mathrm{z}$ natury samonapędzających się rozruchów. Starsze wspólnotowe tożsamości, które od wieków określały strony konfliktu w holenderskim społeczeństwie - konfliktu liberalnej, wolnomyślnej elity mieszczańskiej przeciwko obrońcom kalwinistycznej ortodoksji oraz kalwinizmowi przeciw katolicyzmowi - zostały reaktywowane pod wpływem sił modernizacji. Grupy, które pojawiły się później, jak na przykład pracownicy przemysłowi, nie miały wyboru i musiały przyjąć logikę starszych. W rezultacie wyłoniły się rywalizu-

21 A. van Domburg, Levende schaduwen: Aantekeningen over film, Uitgeverij Het Spectrum: Utrecht 1936, s. 25, 80. 
jące bloki czy też „filary” (zuilen), jak nazywano je w Holandii. Organizując się $\mathrm{w}$ partie polityczne, walczyły one o władzę w rozpoczynającej się erze masowej demokracji. Zdecydowały się także szukać siły w pewnej izolacji, otaczając się kordonem elektoratu przed zewnętrznymi - społecznymi i kulturowymi - wplywami. Ten aspekt kulturowej izolacji w jest szczególnie istotny dla naszej analizy.

Wśród propagatorów poglądów politycznych były tradycyjne media, takie jak prasa, ale też nowsze, jak radio czy film. Naturalną skłonnością każdego ze wspominanych społeczno-kulturalnych segmentów była chęć przejęcia kontroli nad mediami i przepływem informacji. To właśnie stało się z prasą i radiem. Istniały na przykład gazety liberalne i socjalistyczne, kalwińskie i katolickie. Również w późnych latach 20 . fale radiowe były poprowadzone wzdłuż linii oddzielających poszczególne segmenty społeczne. Zarówno produkcja, jak i nadawanie programów radiowych były w pełni kontrolowane przez korporacje założone pod organizacyjną egidą różnorakich „filarów”.

Z filmem było inaczej. Po pierwsze, „filary” nigdy nie odniosły sukcesu w wydzieraniu części rynku dystrybucji filmów, głównie ze względu na fakt, iż nie miały ekonomicznego zaplecza, aby je produkować. We wczesnych latach 30 . rynek zdominowany był przez filmy importowane, mniej więcej na równi niemieckie i amerykańskie, zaś po dojściu Hitlera do władzy w 1933 roku, przez Amerykanów. W latach 1938-1939 udział USA w holenderskim rynku wynosił około 60 procent $^{22}$.

Niebędące w stanie kontrolować ani produkcji, ani dystrybucji filmów, różnorodne społeczno-kulturalne segmenty holenderskiego społeczeństwa musiały samodzielnie wymyślić odpowiedź na wyzwania niezależnego rynku filmowego $\mathrm{w}$ ramach przemystu rozrywkowego. Czasami, mając na horyzoncie utworzenie prawnych regulacji, udawało im się połączyć siły. Ale jedynym przekonaniem, które dzielili wszyscy, był tak zwany „problem kin” (bioscoopvraagstuk). W 1926 roku, dzięki jednogłośnie udzielonemu wsparciu, przyjęto ustawę, której zadaniem było „odeprzeć moralne i społeczne zagrożenia płynące z kin”. Powołano narodową komisję recenzencką. Miała ona sprawdzać wszystkie filmy przed ich premierą, aby ustalić kryteria powiązane $\mathrm{z}$ wiekiem odbiorców, a nawet zakazać wyświetlania tytułów naruszających publiczną moralność.

Bez wątpienia nie było to nic innego jak podstawowa forma obrony w obliczu zagrożenia, które zdaniem wielu wymagało szerszej kulturowej kontrofensywy. Tradycyjne ramy kulturowego nadzoru zostały rozerwane, jak na ironię, przez te same zmiany, które wielu przyjmowało jako postęp: zmniejszenie liczby godzin pracy, zwiększenie dochodów pozostających do dyspozycji, szerszy zakres wyboru dla indywidualnego konsumenta. Konsumpcja i odpoczynek stały się nowymi obszarami wyrastającymi poza ustabilizowane ramy kulturowej kontroli.

${ }^{22}$ Zob. Filmliga 1917-1931, ed. J. Heijs, SUN: Nijmegen 1982. 
W odpowiedzi, każdy ze społeczno-kulturowych bloków w Holandii gorączkowo próbował opracować strategię zdobycia kontroli nad nową kulturą konsumpcji. W ramach prób, aby zorganizować konsumpcję kultury wśród przedstawicieli swoich elektoratów, najczęstszym negatywnym punktem odniesienia stawała się rzeczywistość komercyjnej rozrywki, oferującej tanie doznania, konsumpcję zamiast spełnienia, zapomnienie zamiast uskrzydlenia poprzez edukację.

Zdaniem socjalistów celem polityki kulturowej zawsze powinna być edukacja prowadząca do lepszego świata. Socjalistycznej młodzieży zapewniali więc alternatywne ramy spędzania wolnego czasu, wakacji, tak by czerpała radość z natury i aby wyostrzyła poczucie dystansu do otaczającej ją kapitalistycznej kultury. Jak na ironię, socjalistyczni obserwatorzy, tacy jak na przykład Willem Adriaan Bonger, odnotowywali, że to, co się naprawdę wydarzyło, było niczym więcej, jak tylko repliką ruchu emancypacji kulturowej dokonującego się nieco wcześniej w tym samym stuleciu pod zwierzchnictwem liberalnej burżuazji ${ }^{23}$. Awersja wobec kulturowej erozji przyniesionej przez - zazwyczaj amerykański - przemysł rozrywkowy była jednak popierana znacznie szerzej niż wielu socjalistów zwykło uważać. Wybór języka i argumentów, jakimi się posługiwali, ustanawiając własną wizję socjalistycznej kultury przeciwko kapitalistycznej, przeważnie produkowanej w Ameryce, dał kulturalnej ofensywie dystynktywny posmak. Ukształtował on część szerszej międzynarodowej dyskusji pomiędzy samymi socjalistami, która skupiała się na konturach „Socjalizmu jako ruchu kulturowego”, zgodnie z tym, jak przedstawiał to jeden z najważniejszych belgijskich teoretyków socjalizmu, Hendrik de Man.

Co więcej, zdaniem socjalistów istniała jedna typowa dla nich strategia obrony moralności, która nie mogłaby się narodzić w kręgach liberalno-burżuazyjnych: strategia socjalizowania produkcji i dystrybucji filmowej wraz z uspołecznianiem kin. Propozycję w tym duchu zaprezentowano w 1922 roku w magazynie „De Socialistische Gids” w artykule Davida van Staverena, który później został długoletnim członkiem narodowej komisji recenzenckiej. Wówczas zrezygnował on ze swoich wczesnych radykalnych poglądów, jednak w 1922 roku mógł sobie jeszcze pozwolić na stwierdzenie, że:

Źródłem naszego obecnego stanu jest fakt, iż przemysł filmowy oraz kina są kapitalistyczne, prowadzone i organizowane w celu zbijania kapitału. Prowadzi to do tego, że głównym zmartwieniem nie jest, co jest dobre, co ma największą wartość edukacyjną, ale raczej: jakie filmy pozwolą mi na przyciągnięcie największych tłumów? ${ }^{24}$

23 Zob. T. Beckers, Planning voor vrijheid: Een historisch-sociologische studie van de overheidsinterventie in rekreatie en vrije tijd, Vakgroep sociologie: Wageningen 1983, s. 130.

${ }^{24}$ Davis van Staveren, Een bioscoopwetsontwerp, „De Socialistische Gids” 1922, no. 7, s. 947-959. 
Socjaliści mieli swoją własną, ideologicznie inspirowaną, odporność na film jako przemysł rozrywkowy. W wyimaginowanym świecie srebrnego ekranu i w ciemnościach sali kinowej współcześni uczniowie Karola Marksa dostrzegali „opium dla mas". W artykule z 1931 roku o Marlenie Dietrich, opublikowanym w „De Socialistische Gids”, H. G. Cannegiete stawia sprawę następująco:

$\mathrm{w}$ istocie kino, palarnia opium Zachodu, jest schronieniem broniącym umysł przed niszczycielskimi napaściami, którym musi się on przeciwstawiać w realnym życiu. Tu pozbawieni samokontroli ludzie pogrążają się w marzeniach, niesieni przez odbicia ich własnych pożądliwości i nastrojów ujętych w kształt cieni poruszających się na ekranie. To jest prawda, żywiołowy, naturalny proces chwytania wszystkiego, czego nie przyjąłby racjonalny intelekt ${ }^{25}$.

Jeśli zignorujemy drwiące skojarzenie z palarnią opium, stanowisko to okazuje się niezwykle trafne i może przypominać wcześniejsze obserwacje Huizingi dotyczące wymyślonych światów filmowej publiczności.

Podobne próby kontrolowania aktywności elektoratu w czasie wolnym podejmowali też holenderscy kalwiniści. I tak jak socjaliści, posiadali oni dystynktywny element w swoich staraniach. W przeciwieństwie do innych bloków społeczno-kulturalnych - wśród których wszystkie w ten czy inny sposób zaakceptowały film jako formę sztuki oraz jako medium służące rozrywce - holenderscy kalwiniści dążyli jednak do całkowitego odrzucenia kina. Od okresu reformacji kształtowali tradycję przeciwną przedstawieniom obrazowym. Byli ludźmi Słowa oraz Księgi. Byli najbardziej krytycznie nastawieni wobec, jak określił to Huizinga, zwrotowi ku kulturze ejdetycznej, przejściu od słowa drukowanego do obrazów. Nawet w latach 30. w liberalno-reformatorskim czasopiśmie „Tijd en Taak” Tjeerd Lichthart odnosił się do kina jako „duchowego salonu dla proletariatu”:

Tak długo jak kina będą trwać w dotychczasowej formie, tak długo nie będziemy ich odwiedzać. Dla naszego własnego dobra i dla dobra pozostałych osób. Z określonych powodów nie czujemy się tam jak w domu, mamy wrażenie, że nie przynależymy do tego miejsca. Głównie z poczucia obowiązku wobec poszukujących i pozbawionych wskazówek młodych ludzi w tych pozbawionych głębi czasach.

Aż do zakończenia II wojny światowej kalwiniści nie traktowali jednak filmu poważnie.

Katolicy, podobnie jak liberałowie i burżuazja, dość wcześnie zaakceptowali film jako medium istotne dla kultury. $\mathrm{W}$ równym stopniu jak wspomniane dwa pozostałe bloki, dołączyli oni do poszukiwań nowego krytycznego języka oraz estetyki

25 H. G. Cannegieter, Marlene Dietrich, „De Socialistische Gids” 1931, no. 16, s. $888-894$. 
pasującej do filmu jako nowatorskiej formy sztuki. Jeśli ter Braak i Huizinga wypowiadali się w imieniu elitarnej kultury burżuazyjnej inteligencji, to Jef Last i L. J. Jordaan mediowali pomiędzy obrońcami filmu jako sztuki oraz socjalistami skoncentrowanymi na utrzymywaniu integralności kultury socjalistycznej. Podobnie było wśród katolików, osoby takie jak van Domburg czy jego młodszy kolega B. J. Bertina próbowali przyłączyć się do debaty o filmie ze swoimi przekonaniami estetycznymi i krytycznymi. Jednakże, jak wiadomo, stanowili oni jedynie mniejszość. Katolicy, silniej niż pozostałe grupy, rozpoczęli mocną ofensywę moralną nie tylko po to, by bronić swej trzódki przed zgubnym wpływem produkowanych na masową skalę filmów rozrywkowych, ale także aby tworzyć katolickie filmy przydatne do szerzenia właściwej wizji moralności. Podobnie jak holenderscy socjaliści, których debata stała się częścią międzynarodowej dyskusji na temat „socjalizmu i ruchu kulturowego", katolicy również znajdowali inspiracje za granicą. W 1936 roku ogłoszona została poświęcona filmowi papieska encyklika Vigilanti Cura. Istnieje też wcześniejszy amerykański przykład Legionu Przyzwoitości inspirowanego przez amerykańskich biskupów. Lecz nawet w przypadku braku takich wzorców, w późnych latach 20. holenderscy katolicy wypracowali sposób moralnej obrony przeciwko komercyjnemu rynkowi filmowemu (poprzez zdobycie prawa do ponownej selekcji tytułów kierowanych do dystrybucji w konserwatywnych katolickich regionach kraju). Później, bardziej otwarcie niż inne grupy społeczne, katolicy umieszczali moralne wskazówki w magazynie filmowym „Het Witte Doek”, założonym w 1937 roku przez Katolicką Akcję Filmową. Ton moralnej perswazji można wyczuć na każdej stronie:

Wee Willie Winkie może być obejrzany przez czternastoletnie dzieci. Jednakże niektóre kina wykorzystują to jako okazję do zamieszczania reklam Klubu Shirley Temple. Nasi holenderscy ojcowie i matki są jednak wystarczająco rozsądni, by zabronić swoim dzieciom angażowania się w taką idolizację filmowych gwiazd.

Stała kolumna „O filmie i młodzieży” daje taki przykład:

Wiele przemawia za tym, iż kiedy głód obrazu, głód filmu zostanie zaspokojony oszczędnie i z pedagogiczną intencją oraz pod opieką dorosłych, powinien zostać wyuczony właściwy szacunek dla słowa. Zaleca się więc trenowane młodych zwłaszcza w rozumieniu języka i posługiwaniu się nim. Taki jest wymóg cywilizacji.

Po roku „Het Witte Doek” połączyło się z „Filmfront”, magazynem małej grupy katolickich estetyków filmowych. Czasopismo pod nowym tytułem „Katholiek Filmfront” w twórczym napięciu utrzymywało przy sobie estetyków i obrońców moralności ${ }^{26}$. W porównaniu z innymi grupami społecznymi kato-

26 P. Slot, 'Een vloeken een zegen': De Katholieken en film in Nederland, 1912-1942, University of Amsterdam, M. A. Thesis, 1986. 
licki pogląd na Amerykę i jej produkcję filmową odzwierciedlał pewien ważny szczegól. Ameryka nie była tak łatwo stawiana w roli kulturowego złoczyńcy, być może przez inspirującą pozycję tamtejszego Kościoła Katolickiego.

To zaledwie ogólny zarys różnorodnych frontów kulturowej samoobrony w obliczu wyzwania stwarzanego przez film i kino. Do tego stopnia, że można wręcz mówić o krucjacie przeciwko siłom ciemności, ciemności w sali projekcyjnej. I za każdym razem, gdy ludzie zwykli ulegać tym siłom, poddając się wymarzonemu światu Hollywood, Ameryka znów stawała się celem opozycji. Tylko tym razem nie była to jednak krytyka przeprowadzana na gruncie estetyki i przeciwko Ameryce psującej film jako sztukę, lecz na gruncie moralności, przeciwko Ameryce psującej sferę publiczną. Bez wyraźnego wskazania drogi ludzie nie powinni być wprowadzani (czy raczej: wpuszczani) do mroków kina. Wiele negatywnych poglądów na temat amerykańskiego społeczeństwa i kultury, które inspirowały powszechne odrzucenie amerykańskich filmów przez wielu z czystych estetów, w rzeczywistości powtarzano wśród tych, dla których przedmiotem troski był film jako wyzwanie moralne. Jednakże nasza eksploracja dwóch oddzielnych dyskursów - estetów i moralistów - nie ukazuje jedynie samych analogii.

Esteci do tego stopnia odczuwali potrzebę zdefiniowania swoich ideałów przeciwko wszechobecnemu amerykanizmowi, iż mieli w zwyczaju wznosić sztandar elitarnych norm kulturowych i szerzyć swoją wizję europejskiego dziedzictwa. Podczas gdy esteci zwracali się ku transcendencji niderlandzkiego krajobrazu kulturowego, coś przeciwnego działo się w przypadku moralnej odpowiedzi na film. Ameryka nadal mogła służyć jako obiekt negatywnych skojarzeń - jako prosta metafora dla anonimowych sił społecznych i zmian - jednak gdy trzeba było zdefiniować standardy, moraliści zwykli wycofywać się za linie dzielące holenderskie społeczeństwo. $\mathrm{W}$ ich różnorodnych stanowiskach można dostrzec coś innego niż wyłanianie się konturów zagrożonej kultury europejskiej. Chodziło raczej o kształt holenderskiego krajobrazu kulturowego, który - podczas próby zachowania kulturowej specyfiki wobec niszczącego naporu modernizacji - utwardzał się wokół fundamentalistycznie i bojowo nastawionych grup.

Z angielskiego przełożyli Marcin Chojnacki i Dominika Staszenko 